MichU

DeptE

ResSIE

$\mathrm{D}$

\#⿰ 236
RESEARCH SEMINAR IN INTERNATIONAL ECONOMICS

Department of Economics

The University of Michigan

Ann Arbor, Michigan 48109-1220

SEMINAR DISCUSSION PAPER NO. 236

A Data Set on International Trade in Armaments

for the Major Western Industrialized and

Developing Countries for 1980:

Sources and Methodological Issues*

by

Lisa M. Grobar

Department of Economics

California State University, Long Beach

Long Beach, CA 90840

and

Robert M. Stern

The University of Michigan and Brandeis University

Department of Economics

Brandeis University

Waltham, MA 02254-9110

* This research was supported in part by grants from the Ford Foundation to the Institute of Public Policy Studies at The University of Michigan for a program of study of Economic Issues of National Defense, the Carnegie Corporation to the Office of International Peace and Security at The University of Michigan for a program of study of New Approaches to Attaining International Peace and Security, and from the sanctions project of the Department of Economics at Duke University. We would like to thank John Alfaro for computational assistance and Judith Jackson for typing and editorial assistance. Helpful comments on an earlier version of the paper were received from Ethan Kapstein and an anonymous referee.

July 20, 1989

Address correspondence to:

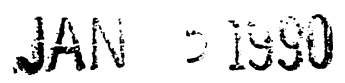

Robert M. Stern

Department of Economics

Brandeis University

Waltham, MA 02254-9110

Telephone: (617) 736-2240

The Sumber and

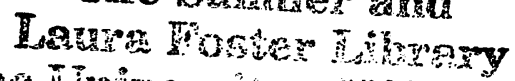

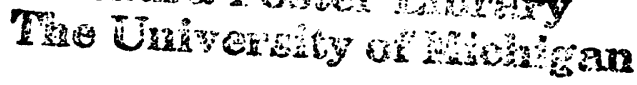



Table 6

Export Arms Trade by ISIC Sector. 1980 in SMIIItons

Developed Countries

\section{Australla}

Austria

Canada

European Community

Belgium-Lux

Denmark

W. Germany

Ireland

I taly

Nether lands

U.K

Finland

Japan

New Zealand

Norway

Sweden

Sw t tzerland

U.S.

Developing Countries

$\begin{array}{lr}\text { Argentina } & 0.0 \\ \text { Brazll } & 1.8 \\ \text { Chile } & 0.0 \\ \text { Colombla } & 0.0 \\ \text { Graece } & 0.0 \\ \text { Indla } & 0.0 \\ \text { Iarael } & 66.4 \\ \text { S. Korea } & 0.1 \\ \text { Mexlco } & 0.0 \\ \text { Portugal } & 2.4 \\ \text { Singapore } & 0.3 \\ \text { Spain } & 1.3 \\ \text { Taiwan } & 0.0 \\ \text { Turkey } & 0.6 \\ \text { Yugosiavia } & 0.0\end{array}$

2.3
1.1
1.9

17.1
40.8
0.6
0.0

1.6

1.3
0.1
1.2

5.2
3.2
6.5

4.8
27.8
16.4

24.0

20.0
63.0

38.2

6

2.3
6.8
11.6
39.0
0.0
389.3
24.4
216.4

2.2

5.7

0.1

6.9

11.2
8.3

0.4
0.0

225.9

0.0
32.4

0.0
0.2
0.0
0.0
0.0
0.0
49.8
0.0
0.0
0.0
0.0
0.0
0.0
0.0
0.0

0.0
0.0
0.0
0.0
0.0
0.0
99.7
0.0
0.0
0.0
0.0
1.4
0.0
0.0
0.1

1.7
2.3
0.1
0.0
4.1
0.0
332.2
19.2
0.5
27.1
0.2
22.3
0.0
0.3
0.3

2.0
49.2
0.0
0.0
2.5
7.0
185.8
159.2
0.5
27.5
0.0
11.0
2.5
8.0
116.0

1.0

103.0

30.1

604.9

306.2

485.0

16.2
345.5
1. 3
21.1
0.1
0.0
71.1
492.0
2181.9

$\begin{array}{rr}0.0 & 14.1 \\ 2081.0 & 2700.7 \\ 1038.0 & 1400.8 \\ 8.0 & 10.0 \\ 977.0 & 1899.9 \\ 235.5 & 293.8 \\ 918.7 & 1621.2\end{array}$

1.1

1.1
21.0

21.0
0.0

22. 7

62.0

155.0
3774.0

5.5
59.7

0.7

22.7

141.4

675.3

6263.3

0.0

0.1

0.3

116.0

97.5
0.0

4.7
151.0

0.2

$0.3 \quad 0.3$

$\begin{array}{rr}0.0 & 6.6 \\ 23.0 & 30.0\end{array}$

199.0

72.0

0.0

933.0

250.5

$6.0 \quad 63.0$

0.0

58.2

2.0

101.0

94.2

4.5

109.9
348.4

All

Sectors

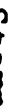


Table 7

Import Arms Trade by ISIC Sector. 1980 in SMIIIIons

Developed Countries

Australia
Austria
Canada

0.5
2.2

2.2
1.9

$$
\begin{aligned}
& 0.0 \\
& 0.0 \\
& 0.0
\end{aligned}
$$

0.1
0.4
0.0

1.2
14.5
3.3

56.5
32.4

42.7

219.0
43.0
216.0

277.3

uropean Community

Belglum-Lux

Denmark

W. Germany

Ireland

I taly

I taly
Nether lands

U.K

3.9
0.2
4.4
12.3
0.0
3.4
2.0
2.0

0.0
0.0
0.0
0.2
0.0
0.0
0.0
0.0

0.7
0.1
0.6
0.3
0.0
0.0
0.1
1.9

13.4
3.3
12.0
86.1
0.1
6.4
26.1
22.8

77.4
51.1
7.5
170.0
3.1
3.7
100.2
51.5

237.0
149.0
19.0
364.0
13.5
59.3
317.0
162.0
129.0
243.0
6.4
155.8
39.2
18.5
64.0

332.3

Finland

Japan

New Zealand

Norway

Switzer land

U.S.

1.1
1.0
1.9
0.4
2.7
4.3
20.3

0.0
0.0
0.0
0.0
0.0
0.0
1.1

0.1
0.0
0.0
0.0
0.0
0.1
1.8

2.4
2.8
1.1
2.6
4.1
4.9
51.6

31.5
57.8

57.8
1.2

1.2
36.6

18.3

3.1
15.9

64.0

92.5
267.0

Developing Countries

Argent Ina
Brazil
Chile
Colombia
Greece
India
Israel
S. Korea
Mexico
Portugal
SIngapore
Spa In
Talwan
Turkey
Yugoslavia

0.1
0.0
0.7
0.0
1.3
0.0
0.2
3.6
0.1
3.2
0.4
4.2
0.0
0.0
0.1

0.0
0.0
0.0
0.0
0.0
0.0
0.0
0.0
0.0
0.0
0.0
0.0
0.0
0.0
0.0

0.1
0.0
0.1
0.2
3.3
0.0
0.0
0.0
0.0
0.1
0.0
0.0
0.1
0.0
0.0

0.9
13.4
2.5
2.0
2.1
3.1
11.5
38.7
0.3
7.7
2.4
9.8
0.2
0.0
0.6

34.5
33.3
100.3
24.2
47.5
145.1
772.7
85.5
1.1
6.7
1.7
52.3
107.0
16.0
60.4

164.0
100.0
148.0
43.0
185.0
542.0
752.0
366.0
11.5
36.0
6.0
187.0
546.0
145.0
120.0

199.6

146.8

251.7

69.5

239.2
690.2

690.2
1536.4

493.8

13.0

53.8

10.5

253.3

653.4

181.1 
Table 8

Developed Countries

\section{Austral ia \\ Austria}

Canada

European Community

Beiglum-Lux

Denmark

W. Germany

Ireland

Ireland

Netherlands

U.K

\section{Finland}

Japan

New Zealand

Norway

Sweden

U.S.

Developing Countries

Argent Ina
Braztl
Chile
Colombla
Greece
India
Israel
S. Korea
Mexlco
Portugal
SIngapore
Spain
Taiwan
Turkey
Yugoslavia

rugosiavta

Net Exports of Arms by ISIC Sector. 1980 in SMllilons

Metal
Products

Nonelectric
Machinery

Machinery

Equipment

Sectors

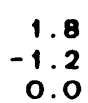

0.6
0.0

1.2
-0.3

4.0
-11.3

-51.7
-4.6

-195.0
-23.0

$-239.1$

1.6

3.2

$-29.3$

$-153.0$

-40.3
-176.4

$\begin{array}{rr}0.5 & -0.0 \\ 1.6 & 0.0 \\ -1.5 & -0.0 \\ -4.7 & -0.2 \\ -0.0 & -0.0 \\ 10.2 & 34.8 \\ 6.0 & 3.3 \\ 41.3 & 32.5\end{array}$

$$
\begin{array}{r}
-0.7 \\
-0.1 \\
-0.3 \\
9.7 \\
-0.0 \\
0.1 \\
6.2 \\
63.0
\end{array}
$$

$$
\begin{array}{r}
-11.1 \\
3.5 \\
-0.4 \\
-47.1 \\
-0.1 \\
382.9 \\
-1.8 \\
193.6
\end{array}
$$

$$
\begin{array}{r}
-0.1 \\
0.7
\end{array}
$$$$
\begin{array}{r}
-0.3 \\
10.3
\end{array}
$$$$
\begin{array}{r}
10.3 \\
-1.9
\end{array}
$$$$
-0.4
$$$$
-1.7
$$$$
\begin{array}{r}
12.8 \\
20.5
\end{array}
$$

$$
\begin{aligned}
& 0.0 \\
& 0.0
\end{aligned}
$$

0.0
0.0

$-0.0$

0.0
0.0

31.4

$$
\begin{array}{r}
-0.0 \\
-0.0 \\
0.4 \\
-0.1
\end{array}
$$$$
\begin{array}{r}
-0.1 \\
224.2
\end{array}
$$

-0.2
2.9
-1.0
-2.6
2.8
6.3
-43.3

$$
\begin{array}{r}
-47.3 \\
-45.6 \\
597.4 \\
136.2 \\
-1.1 \\
481.3 \\
-84.0 \\
294.0 \\
-30.2 \\
-36.8 \\
-1.0 \\
-36.6 \\
52.8 \\
488.9 \\
2166.0
\end{array}
$$

$-134.0$

$-149.0$

2062.0

674.0
-5.5

-5.5
917.7

$-81.5$

756.7

$-192.6$

$-189.6$

2657.1

767.9
-6.7

-6.7
1827.0

1827.0
-151.7

-151.7
1381.1

$-127.9$

$-158.7$

$-222.0$

$-244.8$

$-6.4$

$-10.3$

$-172.8$

$\begin{array}{r}-132.8 \\ \hline\end{array}$

136.5

644.4

3710.0

6108.7

$\begin{array}{rr}-0.0 & 0.0 \\ 1.8 & 0.2 \\ -0.7 & 0.0 \\ -0.0 & 0.0 \\ -1.3 & -0.0 \\ 0.0 & 0.0 \\ 66.2 & 49.8 \\ -3.6 & -0.0 \\ -0.1 & 0.0 \\ -0.8 & 0.0 \\ -0.1 & 0.0 \\ -2.8 & 0.0 \\ -0.0 & -0.0 \\ 0.6 & 0.0 \\ -0.1 & 0.0\end{array}$

-0.1
-0.0
-0.1
-0.2
-3.3
0.0
99.7
0.0
0.0
-0.1
-0.0
1.4
-0.1
0.0
0.1

0.8
-11.1
-2.4
-2.0
1.9
-3.1
320.7
-19.5
0.2
19.4
-2.1
12.5
-0.2
0.3
-0.3

-32.5
15.8
-100.3
-24.2
-44.9
-138.1
-586.8
73.7
-0.7
20.8
-1.7
-41.4
-104.5
-8.0
55.6

-163.0
-2.5
-148.0
-42.7
-185.0
-519.0
-553.0
-294.0
-11.5
-30.0
-6.0
-128.8
-544.0
-44.0
112.0

-194.8
4.1
-251.5
-69.2
-232.6
-660.2
-603.4
-243.3
-12.0
9.3
-9.9
-159.1
-648.9
-51.1
167.2 
Table 9

Export Arms Irade by ISIC Sactor as Percent of Total 1980 Irade

$\begin{array}{ccccc}\text { Wood Rubber Iron } & \text { Metal } & \text { Nonoloctric Electric Transportation } \\ \text { Products } & \text { Steol } & \text { Products } & \text { Machinery Machinery } & \text { Equipment }\end{array}$

Developed Countries

Australla

Austria

Canada

European Community

Belglum-Lux

Denmark

France

W. Germany

Ireland

Italy

Nether lands

$u, k$

Finland

Japari

New Zeal and

Norway

Sweden

Swlezer Inild

u. 5 .

Developing Countries

$\begin{array}{lr}\text { Argent Ina } & 0.1 \\ \text { Brazil } & 0.2 \\ \text { Crile } & 0.0 \\ \text { Colombla } & 0.0 \\ \text { Groece } & 0.0 \\ \text { India } & 0.0 \\ \text { Israel } & 33.4 \\ \text { S. Korea } & 0.0 \\ \text { Mexlco } & 0.0 \\ \text { Portugal } & 0.4 \\ \text { Singapore } & 0.0 \\ \text { Spaln } & 0.1 \\ \text { Talwan } & 0.0 \\ \text { Turkey } & 2.7 \\ \text { Yugeglavia } & 0.0\end{array}$

0.6
0.1

0. 0

0.3

0.3

0. 2

0.0

0.8

0.0

0.2
0.0

0.0
0.0

0.0

3. 6
0.0
0.0

0. 0

0.4

0.0

1. 2

0.2
0.2

0.0
0.0

0.0

0.0

0.0

0.9

0. 2

0.0
0.0
0.0

o. 0

0.0
0.0

0.0

0.8

0. 0

0.0

0.0
0.0

0.0
0.0

0.0

0.0
0.0
0.0

0.0

0.0
0.0
0.0
0.0

00

00
0.0
0.0
0.1

0.1
0.0

0.0

0.3
1.3

0.0

0.0
0.0
0.0
0.0

0.0
0.0

0.0

0.0
2.9

0. 0

0.0

0.0
0.0

0.0

0.0
20.3
0.0

0.0

0.0

0.0

0.0
0.1
0.0
0.0

0.0
0.0

0.0
0.1
0.4
0.1
0.1
0.0
3.2
0.7
1.5

0.2

0.0

0. 2

0.0

0.2

0.0

0.7
0.2
1.7
0.0
9.5
0.0
57.0
5.0
0.2
18.5
0.0
1.3
0.0
0.8
0.0

$\begin{array}{ll}2.5 & 5.0 \\ 2.2 & 2.2 \\ 1.4 & 0.7\end{array}$

2.2
0.7

$\begin{array}{rr}1.0 & 1.5 \\ 0.7 & 0.0 \\ 9.2 & 12.0 \\ 2.1 & 3.3 \\ 0.4 & 3.0 \\ 11.9 & 11.0 \\ 0.4 & 7.1 \\ 5.7 & 6.2 \\ 0.2 & 0.2 \\ 0.1 & 0.1 \\ 0.3 & 0.0 \\ 0.0 & 3.2 \\ 3.2 & 13.5 \\ 15.6 & 13.1 \\ 16.9 & 12.6\end{array}$

1.5
0.0

8

3. 3

1.0

6.2

0.2

0

2

1. 5

2.6

$\begin{array}{rr}3.1 & 0.7 \\ 8.9 & 5.9 \\ 0.0 & 0.0 \\ 0.0 & 1.4 \\ 2.9 & 0.0 \\ 4.9 & 0.4 \\ 33.6 & 31.1 \\ 7.1 & 6.9 \\ 0.3 & 0.0 \\ 9.1 & 2.9 \\ 0.0 & 0.0 \\ 1.5 & 2.3 \\ 0.1 & 0.4 \\ 28.4 & 39.7 \\ 11.9 & 19.4\end{array}$

0. 7

0. 0

1.4

o. 4

1. 1

6. 9

2.9

3

0.4

19.4 
Table 10

Import Arms Irade by ISIC Sector as Percent of Total 1980 Irade

Wond 8 Rubber

Products
0. 1

0. 3

Austria

European Communlty

Belglum-Lux

Denmark

France

W. Germany

Ireland

I taly

Ne ther lands

U.K

Finland

Japan

New Zealand

Norway

Sweden

Switzer land

U.

Developing Countries

Arkesilline
ilinkli
Chlile
Colombla
Greece
India
Israel
S. Korea
Mexlco
Portugal
SIngapore
Spain
Talwan
Turkey

rugos lavia
Metal
Products

Steel

0.2
0.0
0.1
0.2
0.0
0.1
0.1
0.0
0.3
0.0
1.4
0.1
0.3
0.4
0.3

0.0

0.0

0.0
0.0

0.0

0.0
0.6

None lectrlc

Eloctric

Transportation

Equ I pmont 



\title{
A Data Set on International Trade in Armaments for the Major Western Industrialized and Developing Countries for 1980: Sources and Methodological Issues
}

\author{
by \\ Lisa M. Grobar \\ California State University, Long Beach \\ and \\ Robert M. Stern \\ The University of Michigan and Brandeis University
}

\section{Introduction}

The purpose of our paper is to present a data set on international trade in armaments by country/region of origin and destination for the major Western industrialized and developing countries for 1980. This data set includes estimates of the breakdown of military trade into four sectors: military ships; military aircraft; military communications equipment; and military goods in the SITC category $951,{ }^{1}$ which includes trade in tanks, ammunitions, and small arms. What distinguishes our data set is that it is more disaggregated than what is currently available from existing data sources, and it includes, wherever possible, estimates of the magnitude and direction of arms trade flows. In addition, we provide a breakdown of the arms trade according to the sectors in which the arms are being produced domestically. In constructing the data set, we have had occasion to review the main existing data sources on arms trade and to deal with a number of conceptual issues in measuring this trade and adapting it for use in the Michigan Computational Model of World Production and Trade.

${ }^{1}$ SITC refers to the Standard International Trade Classification, which is the basis for reporting and classifying United Nations (UN) trade data. 
In view of the recent reduction in international conflicts and tensions and renewed efforts for disarmament, it will no doubt be important to consider the possible economic effects that may be involved if the level and pattern of military expenditures and trade are changed significantly. Reasonably comprehensive data on trade in armaments will thus be needed for analytical purposes. In the belief that other investigators might find our data set useful or wish to extend it to other years, it appeared to us worthwhile therefore to provide some details on what we have done.

We begin in Section 2 with a discussion of the existing data sources. Methodological issues are dealt with in Section 3. We then present in Section 4 a series of tables that comprise our data set on armaments trade in 1980. Some conclusions and implications for research are contained in Section 5.

\section{Data Sources}

Our data sources included primarily publications of various years of the U.S. Arms Control and Disarmament Agency (ACDA), the United Nations (UN), the Stockholm International Peace Research Institute (SIPRI), Leontief and Duchin (1983), Pierre (1982), and Ball and Leitenberg (1983). These data sources are described below.

Data on aggregate imports and exports of armaments are available from the ACDA publication, World Military Expenditures and Arms Transfers, various issues, from 1963 to the present. ACDA data on the value of arms imports and exports are provided only in aggregate form and include the value of transfers of "conventional" military equipment and material and licensing fees. Conventional weapons cover tactical guided missiles and rockets, military aircraft, naval vessels, armored and nonarmored military vehicles, military communications and electronic equipment, artillery, infantry weapons, small arms, ammunition, parachutes and uniforms. The following items are excluded: nuclear, chemical, and biological weapons and strategic missile systems, foodstuffs, medical equipment, and other items with potentially civilian uses. Construction, training, 
and technical services are also excluded. The data reflect the value of goods actually delivered in a given year.

Although ACDA data on the value of arms transfers are no doubt the most comprehensive source available, these data are subject to many criticisms that should be kept in mind when interpreting any empirical results obtained with the data. ACDA obtains their data primarily from U.S. government sources, in particular, from the Defense Intelligence Agency's (DIA) Conventional Arms Transfers, which is a biannual compilation of conventional arms transfers that is not made available to the public. Brzoska (1982) argues that ACDA coverage of the production and export of arms in countries other than the United States and USSR is incomplete. This applies especially to France, West Germany, Israel, and the United Kingdom. He speculates that this may reflect a relative lack of interest on the part of U.S. intelligence agencies in the arms trade conducted by the smaller suppliers. This criticism appears to be well grounded, as numerous sources have published data on Western European, Israeli, and South American arms exports that are greater in magnitude than the ACDA data. In response to this criticism, we examined the arms trade data for those countries quite carefully in deriving our data set, and substituted data from other sources when the ACDA data were thought to understate the true values.

Data on trade in certain types of military equipment are available from the UN publication, Yearbook of International Trade Statistics. Starting in 1980, the UN Yearbook has a listing for trade in "firearms, ammunition" (SITC code 951) which includes: tanks and other armored fighting vehicles, arms of war, ammunitions, parts of arms, artillery weapons, machine guns, submachine guns, revolvers and pistols, side-arms (swords, bayonets, etc.), bombs, grenades, torpedoes, mines, guided weapons, and missiles.

These UN data are uniformly smaller than the trade data in the ACDA publication, because the UN statistics are not as comprehensive as the ACDA statistics. The UN data under SITC 951 exclude the following categories of weapons that are 
included in the ACDA data: military telecommunications expenditures, purchase of military aircraft and aircraft parts, warships, and licensing fees. Trade in some of these omitted categories is listed in the UN Yearbook under SITC 792 (aircraft, helicopters, and associated parts and equipment), 793 (naval vessels), and probably under 761 (telecommunications, sound recording and reproducing apparatus and equipment). However, little information is given by the UN source on the proportion of each category that represents military use and that which represents civilian use. Some countries explicitly state in the "Country Notes" section of the Yearbook that trade in military goods is not reported. But it is not clear whether or not military trade is included in the data reported by countries that do not mention military trade in the Country Notes.

The UN trade data are reported by individual countries on a voluntary basis. Therefore, a country wishing for any reason to overstate or understate arms exports can easily do so in the data it provides to the UN. ${ }^{2}$ In addition, the UN trade statistics are probably less useful than the ACDA data in analyzing arms trade flows since major items such as trade in military aircraft and naval vessels are excluded. Furthermore, although the Yearbook has been published since 1950, data under SITC 951 have only been separately listed since 1980 . However, we did find the UN data to be a valuable source in determining the magnitude of trade in small arms. The methodology that we employed in integrating the UN and ACDA data is described below in Section 3.

The Stockholm International Peace Research Institute (SIPRI) publication, World Armaments and Disarmament Yearbook, is another source that provides data on the value of the international trade in arms. However, SIPRI only provides data on the transfer of "major weapons," which is a less inclusive category of goods than that included in the ACDA figures. SIPRI gives data on the value of arms exports for the United States,

\footnotetext{
${ }^{2}$ In order to illustrate the kinds of discrepancies that can arise when using the UN data, we constructed a table that shows SITC 951 exports for the 34 countries of the Michigan computational model as reported by the exporting country and as reported by the recipient countries. It appears, for example, that not all countries receiving 951-type arms exported by the United States reported those imports. Further details are available on request.
} 
Soviet Union, France, United Kingdom, France, West Germany, Italy, China, and the Third World (as an aggregate). In addition, SIPRI publishes an Arms Trade Register, which includes recipient and supplier country, number of weapons ordered, weapon description, and order and delivery dates. However, the monetary values for two-way trade in arms are seldom published. Because of this, SIPRI data are useful in estimating the direction, but not the magnitude of the arms trade.

Leontief and Duchin, in their book, Military Spending (1983), provide tables (pp. 16-17) of estimates of the proportion of the ACDA data on aggregate imports and exports of arms that correspond to the following categories: military aircraft, warships, tanks, missiles, and "other," where the category "other" is evenly divided among military communications equipment, ammunition n.e.c., small arms, small arms ammunition, and other ordnance. They provide estimates on the decomposition of the ACDA data on arms imports and exports by sector for 15 regions of the world. According to the authors (p. 16), these estimates were produced on the basis of “... the analysis, comparison and reconciliation of information appearing in many sources, primarily SIPRI (various years)."

Ball and Leitenberg (1983) provide a fairly detailed discussion of arms production and exports of the United States, Soviet Union, France, Germany, Sweden, Czechoslovakia, Italy, Israel, and other developing countries. For each country, details are given on: the size of the defense industry; its organization and sectoral composition, including employment statistics; the profitability of the defense industry, including the profitability of exports of arms; and information on defense budgets and military procurement policies. As explained below, the Ball and Leitenberg data were used to supplement the ACDA and UN data on the arms exports of these countries. Pierre (1982) also discusses Israeli arms production and sales.

\section{Methodology}

We undertook the construction of a data set on world trade in armaments for 1980 in order to estimate the sectoral output and employment effects of this trade in the 
major Western industrialized and developing countries. ${ }^{3}$ The following is a description of the methodology employed in constructing our data set. ${ }^{4}$

Data on aggregate arms imports and exports were obtained from the annual ACDA publication mentioned earlier. These data were then broken down into four categories as follows: (1) military aircraft; (2) military ships; (3) military communications equipment; and (4), a category that corresponds to SITC 951 that covers all other types of military goods including missiles, tanks, guns, ammunition, etc.

Using the above sources, the data were disaggregated according to the following procedure: (a) the data on trade in SITC 951 were found in the UN Yearbook of International Trade Statistics; and (b) tables estimating the (proportional) decomposition of military imports and exports by sector for 15 regional groups in Leontief and Duchin (1983, pp. 16-17) were applied to the aggregate ACDA data. When the SITC 951 UN import or export value was higher (or lower) than the Leontief-derived estimate, the difference was divided by three and added to (or subtracted from) the three other categories of aircraft, ships, and communications equipment. Ball and Leitenberg (1983) was also used as a source of information on the amount and direction of arms trade flows. This source was used in place of ACDA data when aggregate ACDA imports or exports were thought to be too small (e.g., the case of Israel's exports).

We then sought to estimate the direction of the arms trade on a bilateral basis. "Direction of Trade" tabulations were constructed for each of the 34 countries in the Michigan model. These tabulations reflect information from ACDA, SIPRI, and Ball and Leitenberg. ACDA has published data on the direction of trade of major suppliers, cumulative for 1978-82, in World Military Expenditure and Arms Transfers, 1985 edition.

${ }^{3}$ See Grobar, Stern, and Deardorff (1989).

${ }^{4}$ Detailed notes were kept on the methodology employed in deriving the arms trade data for all countries in the Michigan model. These notes are available upon request. For a description of the Michigan model, see Deardorff and Stern (1986). Since our focus was on the military trade of the major Western countries, we have excluded the military trade of the Soviet Union and other socialist countries from our data set. 
Major suppliers are defined as: Soviet Union, United States, France, United Kingdom, West Germany, Italy, Czechoslovakia, Poland, Romania, and China.

These data were used to calculate the direction of arms exports from the United States, France, United Kingdom, West Germany, and Italy to each country in the model and to various regions on a proportional basis. These percentages are based on the ACDA Direction of Trade tabulations for each of the exporters listed above and for the recipient countries. For example, the ACDA source indicates that about two percent of U.S. arms exports were sold to African countries during the 1978-82 period. Therefore, in Table 1, total African purchases of U.S. arms in 1980 are estimated at $\$ 109$ million, which is about two percent of total U.S. arms exports in that year. ACDA was the main source used in determining the direction of trade for the major arms exporters.

For the developing country exporters, the SIPRI Arms Trade Register was used to determine the pattern of trade. The Register indicates the type of weapons being bought and sold by developing and developed countries. However, it does not estimate the value of the trade. Therefore, the SIPRI information is reflected in the tables where asterisks indicate that evidence of trade occurring between the country and the region was found but the exact amount of that trade is not known. Ball and Leitenberg was also used in some cases to determine direction of trade when other sources were not sufficiently informative.

Direction of trade data for SITC 951 are available from the UN trade tapes for many of the 34 countries in the Michigan model. For about 12 countries, a methodology similar to that employed in the case of aircraft, ships, and communications equipment was used to estimate the direction of trade breakdown of each country's trade in SITC 951 goods.

In order to integrate the arms trade data described above with the trade data used in the Michigan model, it was necessary to decide what proportions (if any) of total 
(UN reported) trade in aircraft, ships, and communications equipment reflected trade in military aircraft, ships, and communications equipment.

This was done on a country-by-country basis, using the following information:

1. Country Notes in the 1980 UN Yearbook of International Trade Statistics. Some countries indicated in the Notes that they did not report any trade in military goods. For these countries, the proportion was determined to be zero.

2. In a few cases, the ACDA-based estimates of trade in military ships/aircraft/ communications equipment were larger than, or large relative to, total trade in those goods. In these cases it seemed reasonable to assume that the trade in military goods was not reflected in the UN data. For other countries, the military trade was assumed to be included in the UN trade data.

The final step was to concord the data to the ISIC sectors of the Michigan model as follows. ${ }^{5}$ The trade in military ships and aircraft concords completely to ISIC 384 , transport equipment. The trade in military communications equipment concords completely to ISIC 383 , electrical machinery. The trade in SITC 951 concords to six different ISIC sectors, as follows: wood products (331), rubber products (355), iron and steel (371), metal products (381), nonelectric machinery (382), and electrical machinery $(383) .^{6}$ As mentioned earlier, we have used the concorded data to analyze the output and employment effects of armaments trade for the major Western countries.

\section{International Trade in Armaments for 1980}

The results of our efforts described above are presented in Tables 1-5. The tables show, respectively, the total 1980 military exports and the separate categories of military

\footnotetext{
${ }^{5}$ ISIC refers to the International Standard Industrial Classification, which is the system used in the UN reporting and classification of industrial statistics.

${ }^{6}$ The SITC 951 data are broken down on the UN trade tape into six subcategories (951.01-951.06). These subcategories were concorded to ISIC sectors as follows: 951.01, half each to ISIC 371 and $382 ; 951.02$ to ISIC $382 ; 951.03,1 / 3$ each to ISIC 331,355 , and $382 ; 951.04$ to ISIC $381 ; 951.05$ to ISIC 382 ; and $951.06,1 / 2$ each to ISIC 382 and 383.
} 
ships, military communications equipment, military aircraft, and military goods in the SITC category 951 by country of origin and destination. To conserve space, only the major exporting countries are shown and the destinations are broken down for the major industrialized and developing countries and for the regions that comprise the "rest-ofworld." The "rest-of-world" trade includes the countries in Africa, Latin America, the Middle East, Asia, and the Warsaw Pact that are not in the Michigan model. There were several exporting countries for which there was insufficient information available to construct quantitative estimates of the direction of their military trade. Asterisks in the "rest-of-world" section of the tables indicate that there exists some documentation of military trade occurring between that country and region.

According to Table 1 , total military exports in 1980 by the major Western industrialized and developing countries were approximately $\$ 18.3$ billion. ${ }^{7}$ This constituted about $10 \%$ of total world trade in that year. The United States accounted for $34.2 \%$ of total military exports, followed by France (14.7\%), Italy (10.4\%), the United Kingdom (9.8), and Israel (5.5\%). About $39 \%$ of the total exports went to the major Western industrialized and developing countries and the remaining $61 \%$ to the rest of world, chiefly the Middle East. It is evident that the United States was the chief supplier to the major industrialized and developing countries. France was the largest exporter to Africa and second to the United States in the Middle East. The details concerning the exports of military ships, communications equipment, aircraft, and the SITC categories reveal the importance of the latter two types especially for the United States.

${ }^{7}$ The data in Table 1 understate the value of world trade in armaments since, as noted above, they do not include the exports and imports of the Soviet Union, other Eastern Bloc countries, and the Peoples Republic of China (PRC). According to Grimmett (1988, p. CRS-55), arms deliveries to the Third World in 1980 by the Socialist countries were larger in total than for the Western countries combined. The estimates are $\$ 13.9$ billion for the Soviet Union, $\$ 1.2$ billion for other Bloc countries, and $\$ 0.3$ billion for the PRC. The Middle East (particularly Iran and Iraq) and South Asia were the largest recipients of these arms transfers. 
Tables 6-8 show the value of arms exports, imports, and net exports for 1980 for the countries in the Michigan model concorded to the seven ISIC sectors involving military trade. Tables 9 and 10 show this military trade as a proportion of total exports and imports in the individual sectors. It is interesting to note that, for the industrialized countries, military exports accounted for more than $10 \%$ of total exports of electric machinery and transportation equipment for France, Italy, Switzerland, and the United States. Military exports appeared to represent a very sizable proportion of Israel's exports in all of the categories listed. Relatively large military exports of electric machinery and transportation equipment were also recorded for Turkey and Yugoslavia. Military imports were a comparatively small proportion of total sectoral imports for the industrialized countries, but they were quite substantial for electric machinery and transportation equipment in several of the developing countries listed. ${ }^{8}$

\section{Conclusions and Implications for Research}

Our objective was to construct a data set representative of the arms trade for 1980 that provides information on the four major categories of this trade and the breakdown by country of origin and destination as well as a sectoral breakdown of the exports and imports by ISIC categories for the major industrialized and developing countries. While existing sources provide some information on the composition and direction of the arms trade, our arms trade data set is an attempt to obtain more precise estimates of this trade for individual countries. While exact values have been assigned in each category and direction of the arms trade, our data set is best interpreted as representative of the 1980 arms trade given that our estimates are based on limited available information and assumptions that we made in specific cases.

One important benefit of creating such an arms trade data set is that it can be used to calculate the effects that changes in the level and pattern of the arms trade may

\footnotetext{
${ }^{8}$ As mentioned above, transportation equipment (ISIC 384 ) includes both military ships
} and aircraft, which are covered in Tables 3 and 4 , respectively. 
have on sectoral output and employment in individual countries. In addition, the direction of trade data that we have constructed allows for the analysis of the level and pattern of the arms trade on a bilateral basis. Further, our procedures may be extended to years other than 1980 in case there is interest in analyzing changes over time on a disaggregated basis. ${ }^{9}$ Finally, a detailed arms trade data set may be useful in analyzing the political considerations and alliances governing this trade, as, for example, in Glismann and Horn (1988).

${ }^{9}$ In this connection, there is reason to believe - see Grimmett (1988) - that arms shipments fluctuate considerably from year to year and do not follow a consistent trend. 


\section{References}

Ball, Nicole and Milton Leitenberg (eds.). 1983. The Structure of the Defense Industry. London: Croom Helm.

Brzoska, Michael. 1982. “Arms Transfer Data Sources," Journal of Conflict Resolution 26 (1), 77-108.

Deardorff, Alan V. and Robert M. Stern. 1986. The Michigan Model of World Production and Trade. Cambridge, MA: The MIT Press.

Glismann, Hans H. and Ernst-Jurgen Horn. 1988. "International Arms Trade: Revealed Political Preferences or Cartel Behaviour?" Kiel Working Paper No. 318, The Kiel Institute for World Economics.

Grimmett, Richard F. 1988. "Trends in Conventional Arms Transfers to the Third World by Major Supplier, 1980-1987," CRS Report for Congress 88-352 F, Congressional Research Service, The Library of Congress.

Grobar, Lisa M., Robert M. Stern, and Alan V. Deardorff. 1989. "The Economic Effects of International Trade in Armaments in the Major Western Industrialized and Developing Countries," Defence Economics, forthcoming.

Leontief, Wassily and Faye Duchin. 1983. Military Spending. New York: Oxford University Press.

Pierre, Andrew J. 1982. The Global Politics of Arms Sales. Princeton, NJ: Princeton University Press.

Stockholm International Peace Research Institute (SIPRI). Arms Trade Register, various years.

Stockholm International Peace Research Institute (SIPRI). World Armaments and Disarmament Yearbook, various years.

United Nations. 1980. Yearbook of International Trade Statistics.

United States Agency for Arms Control and Disarmament. World Military Expenditures and Arms Transfers, various issues. 
Table 1

Source and Destination of Total Trade in Armaments for the Major Western Industrialized and Developing Countries, 1980 (Millions of U.S. Dollars)

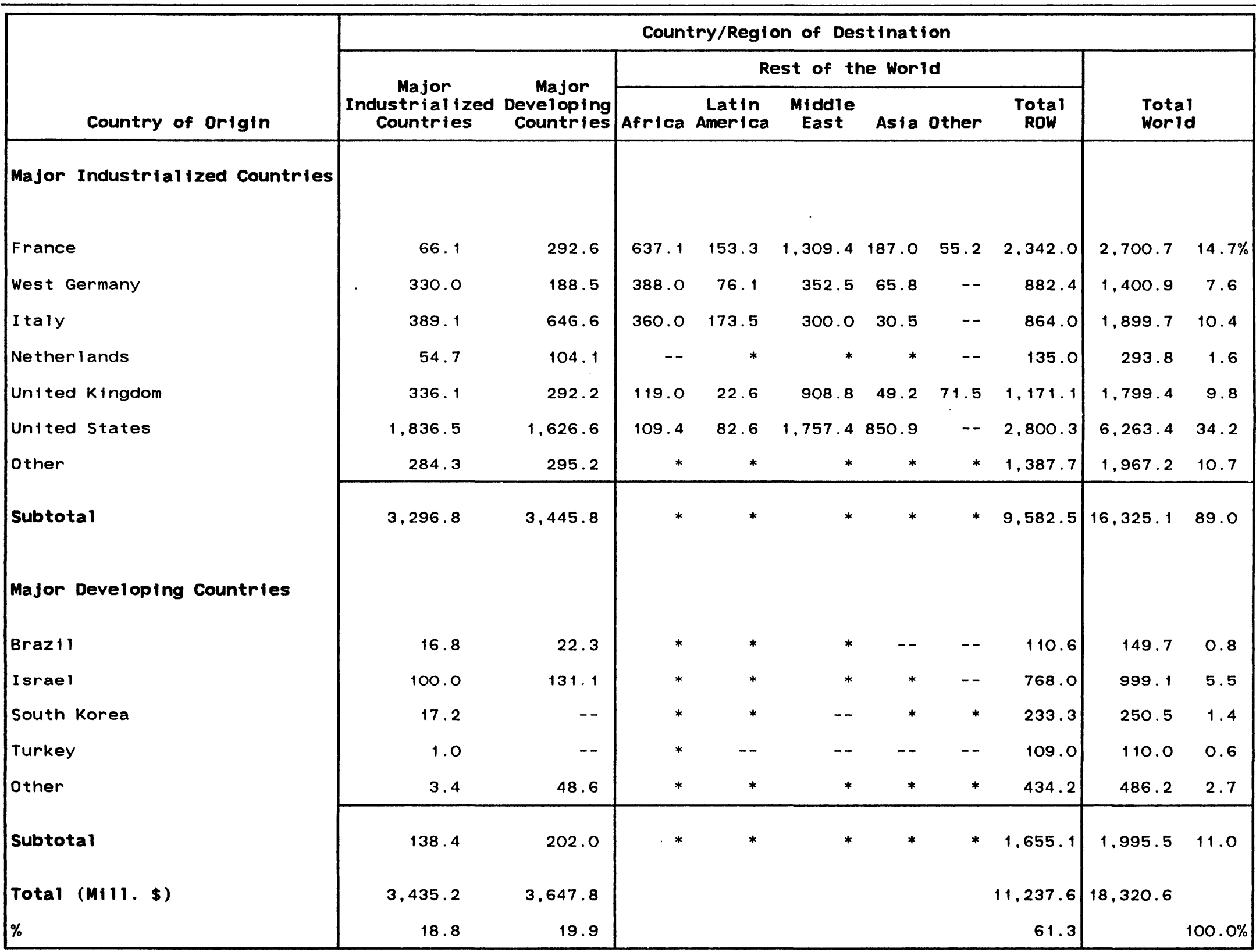


Note: Greece, Portugal, and Spain are included in industrialized countries in Tables 1-5 but are shown as developing countries in subsequent tables. Warsaw Pact and People's Republic of China (PRC) are included in Other ROW. The data exclude arms exports and Imports of the Soviet Unton, other Eastern Bloc countries, and the PRC to one another and to all other countries/regtons.

*Indicates that evidence of trade is occurring between the country and region was found in at least one source, but that the exact amount of that trade is not known. 
Table 2

Source and Destination of Trade in Military Ships for the

Major Western Industrialized and Developing Countries, 1980

(Millions of U.S. Dollars)

\begin{tabular}{|c|c|c|c|c|c|c|c|c|c|c|}
\hline \multirow[b]{3}{*}{ Country of Origin } & \multicolumn{10}{|c|}{ Country/Region of Destination } \\
\hline & \multirow{2}{*}{$\begin{array}{c}\text { Major } \\
\begin{array}{c}\text { Industrial ized } \\
\text { Countries }\end{array}\end{array}$} & \multirow{2}{*}{$\begin{array}{c}\text { Major } \\
\text { Developing } \\
\text { Countries }\end{array}$} & \multicolumn{6}{|c|}{ Rest of the World } & \multirow{2}{*}{\multicolumn{2}{|c|}{$\begin{array}{l}\text { Total } \\
\text { World }\end{array}$}} \\
\hline & & & Africa & $\begin{array}{l}\text { Latin } \\
\text { America }\end{array}$ & $\begin{array}{c}\text { Middle } \\
\text { East }\end{array}$ & Asia & other & $\begin{array}{c}\text { Total } \\
\text { ROW }\end{array}$ & & \\
\hline \multicolumn{3}{|c|}{ Major Industrialized Countries } & & & & & & & & \\
\hline France & 12.1 & 87.8 & 179.0 & 42.1 & 368.0 & 53.0 & 15.0 & 657.1 & 757.0 & $25.8 \%$ \\
\hline West Germany & 36.7 & 30.5 & 126.4 & 34.4 & 113.0 & 31.0 & -- & 304.8 & 372.0 & 12.7 \\
\hline Italy & 13.1 & 63.2 & 118.1 & 52.0 & 97.0 & 6.5 & -- & 273.6 & 349.9 & 11.9 \\
\hline Nether lands & 13.0 & 63.0 & -- & $*$ & * & $*$ & -- & 96.5 & 172.5 & 5.9 \\
\hline United Kingdom & 32.3 & 56.4 & 5.0 & 1.0 & 38.0 & 2.0 & 3.0 & 49.0 & 137.7 & 4.7 \\
\hline United States & 324.1 & 231.6 & 9.3 & 3.5 & 109.5 & 22.0 & -- & 144.3 & 700.0 & 23.8 \\
\hline other & 20.9 & 83.9 & * & * & * & * & $*$ & 59.4 & 164.2 & 5.5 \\
\hline Subtotal & 452.2 & 616.4 & * & * & * & * & $*$ & $1,584.7$ & 2.653 .3 & 90.3 \\
\hline \multicolumn{11}{|l|}{ Major Developing Countries } \\
\hline Brazil & 7.5 & 10.4 & $*$ & $*$ & $*$ & -- & -- & 53.6 & 71.5 & 2.4 \\
\hline Israel & 13.0 & 15.0 & * & * & -- & -- & -- & -- & 28.0 & 1.0 \\
\hline South Korea & -- & -- & -- & -- & -- & -- & -- & -- & -- & -- \\
\hline Turkey & -- & -- & $*$ & -- & -- & -- & -- & 42.0 & 42.0 & 1.4 \\
\hline Other & -- & 22.0 & * & $*$ & $*$ & $*$ & * & 121.0 & 143.0 & 4.9 \\
\hline Subtotal & 20.5 & 47.4 & $*$ & $*$ & $*$ & $*$ & * & 216.6 & 284.5 & 9.7 \\
\hline Total (Mill. \$) & 472.7 & 663.8 & & & & & & $1,801.3$ & $2,937.8$ & \\
\hline$\%$ & 16.1 & 22.6 & & & & & & 61.3 & & $100.0 \%$ \\
\hline
\end{tabular}


Note: Greece, Portugal, and Spain are included in industrialized countries in Tables 1-5 but are shown as developing countries in subsequent tables. Warsaw Pact and People's Republic of China (PRC) are included in Other ROW. The data exclude arms exports and imports of the Soviet Union, other Eastern Bloc countries, and the PRC to ROW. The data exclude arms exports and imports
one another and to all other countries/regions.

*Indicates that evfdence of trade occurring between the country and region was found in at least one source, but that the exact amount of that trade is not known. 
Table 3

Source and Destination of Trade in Military Communications Equipment for the Major Western Industrialized and Developing Countries, 1980

(Millions of U.S. Dollars)

\begin{tabular}{|c|c|c|c|c|c|c|c|c|c|c|}
\hline \multirow[b]{3}{*}{ Country of Origin } & \multicolumn{10}{|c|}{ Country/Region of Destination } \\
\hline & \multirow{2}{*}{$\begin{array}{c}\text { Major } \\
\text { Industrialized } \\
\text { Countries }\end{array}$} & \multirow{2}{*}{$\begin{array}{c}\text { Major } \\
\text { Developing } \\
\text { Countries }\end{array}$} & \multicolumn{6}{|c|}{ Rest of the World } & \multirow{2}{*}{\multicolumn{2}{|c|}{$\begin{array}{l}\text { Total } \\
\text { World }\end{array}$}} \\
\hline & & & Africa & $\begin{array}{l}\text { Latin } \\
\text { America }\end{array}$ & $\begin{array}{l}\text { Middle } \\
\text { East }\end{array}$ & Asia & other & $\begin{array}{l}\text { Total } \\
\text { ROW }\end{array}$ & & \\
\hline \multicolumn{11}{|c|}{ Major Industrialized Countries } \\
\hline France & 12.7 & 70.9 & 139.4 & 32.5 & 288.0 & 41.0 & 10.5 & 511.4 & 595.0 & $18.0 \%$ \\
\hline West Germany & 143.1 & 27.5 & 55.0 & 3.0 & 57.4 & 2.0 & -- & 117.4 & 288.0 & 8.7 \\
\hline Italy & 49.6 & 186.0 & 1.9 & 1.0 & 1.5 & 1.0 & -- & 5.4 & 241.0 & 7.3 \\
\hline Nether 1 ands & 10.2 & 2.0 & -- & -- & -- & -- & -- & -- & 12.2 & 0.4 \\
\hline United Kingdom & 45.5 & 43.0 & 22.5 & 3.5 & 174.5 & 10.5 & 13.5 & 224.5 & 313.0 & 9.5 \\
\hline United States & 123.7 & 173.2 & 14.6 & 14.0 & 253.4 & 141.1 & -- & 423.1 & 720.0 & 21.8 \\
\hline other & 23.5 & 81.8 & * & $*$ & $*$ & $*$ & $*$ & 552.7 & 658.0 & 20.0 \\
\hline Subtotal & 408.3 & 584.4 & $*$ & $*$ & $*$ & $*$ & $*$ & $1,834.5$ & 2.827 .2 & 85.7 \\
\hline \multicolumn{11}{|l|}{ Major Developing Countries } \\
\hline Braz 11 & 5.0 & 7.0 & * & * & $*$ & -- & -- & 36.0 & 48.0 & 1.5 \\
\hline Israel & 15.0 & 46.0 & * & * & -- & * & -- & 75.0 & 136.0 & 4.1 \\
\hline South Korea & -- & -- & -- & -- & -- & $*$ & -- & 140.0 & 140.0 & 4.2 \\
\hline Turkey & -- & -- & * & -- & -- & -- & -- & 8.0 & 8.0 & 0.2 \\
\hline Other & -- & 5.0 & * & * & $*$ & $*$ & $*$ & 139.1 & 139.1 & 4.3 \\
\hline Subtotal & 20.0 & 58.0 & * & * & $*$ & * & $*$ & 398.1 & 476.1 & 14.3 \\
\hline Total (Mil1.\$) & 428.3 & 642.4 & & & & & & $2,232.6$ & $3,303.3$ & \\
\hline$\%$ & 13.0 & 19.4 & & & & & & 67.6 & & $100.0 \%$ \\
\hline
\end{tabular}


Note: Greece, Portugal, and Spain are included in industrialized countries in Tables 1-5 but are shown as developing countries in subsequent tables. Warsaw Pact and People's Republic of China (PRC) are included in Other ROW. The data exclude arms exports and imports of the Soviet Union, other Eastern Bloc countries, and the PRC to one another and to all other countries/regions.

*Indicates that evidence of trade is occurring between the country and region was found in at least one source, but that the exact amount of that trade is not known. 
Table 4

Source and Destination of Trade in Military Aircraft for the Major Western Industrialized and Developing Countries, 1980 (Millions of U.S. Dollars)

\begin{tabular}{|c|c|c|c|c|c|c|c|c|c|c|}
\hline \multirow[b]{3}{*}{ Country of Origin } & \multicolumn{10}{|c|}{ Country/Region of Destination } \\
\hline & \multirow{2}{*}{$\begin{array}{l}\text { Major } \\
\text { Industrialized } \\
\text { Countries }\end{array}$} & \multirow{2}{*}{$\begin{array}{l}\text { Major } \\
\text { Developing } \\
\text { Countries }\end{array}$} & \multicolumn{6}{|c|}{ Rest of the World } & \multirow{2}{*}{\multicolumn{2}{|c|}{$\begin{array}{l}\text { Total } \\
\text { World }\end{array}$}} \\
\hline & & & Africa & $\begin{array}{l}\text { Latín } \\
\text { America }\end{array}$ & $\begin{array}{c}\text { Middle } \\
\text { East }\end{array}$ & Asia & other & $\begin{array}{c}\text { Total } \\
\text { ROW }\end{array}$ & & \\
\hline Major Industrialized Countries & & & & & & & & & & \\
\hline France & 32.1 & 130.1 & 315.5 & 78.0 & 646.8 & 92.0 & 29.5 & 1.161 .8 & $1,324.0$ & $18.0 \%$ \\
\hline West Germany & 98.5 & 119.7 & 201.5 & 37.3 & 177.5 & 31.5 & -- & 447.8 & 666.0 & 9.1 \\
\hline Italy & 52.5 & 288.0 & 111.0 & 64.0 & 95.5 & 16.0 & -- & 286.5 & 627.0 & 8.5 \\
\hline Nether 1 ands & 24.5 & 38.5 & -- & -- & -- & -- & -- & -- & 63.0 & 0.9 \\
\hline United Kingdom & 154.4 & 119.6 & 51.7 & 10.3 & 393.2 & 20.7 & 31.1 & 507.0 & 781.0 & 10.6 \\
\hline United States & 1.380 .2 & 1.213 .7 & 29.5 & 12.5 & 365.6 & 72.5 & -- & 480.1 & $3,074.0$ & 41.8 \\
\hline Other & 20.0 & 108.5 & * & * & * & * & * & 187.0 & 315.5 & 4.2 \\
\hline Subtotal & 1.762 .2 & 2.018 .1 & $*$ & * & * & * & * & $3,070.2$ & 6.850 .5 & 93.1 \\
\hline \multicolumn{11}{|l|}{ Major Developing Countries } \\
\hline Brazil & 3.0 & 3.8 & $*$ & * & * & -- & -- & 19.2 & 26.0 & 0.4 \\
\hline Israel & 50.0 & 26.1 & $*$ & * & -- & $*$ & -- & 94.9 & 171.0 & 2.3 \\
\hline South Korea & -- & -- & -- & -- & -- & $*$ & -- & 72.0 & 72.0 & 1.0 \\
\hline Turkey & -- & -- & $*$ & -- & -- & -- & -- & 59.0 & 59.0 & 0.8 \\
\hline Other & -- & 21.5 & * & * & * & $*$ & $*$ & 158.0 & 179.5 & 2.4 \\
\hline Subtotal & 53.5 & 51.4 & * & * & * & * & * & 419.4 & 524.3 & 6.9 \\
\hline Total (Mill. \$) & 1.815 .7 & $2,069.5$ & & & & & & $3,489.6$ & 7.374 .8 & \\
\hline$\%$ & 24.6 & 28.1 & & & & & & 47.3 & & $100.0 \%$ \\
\hline
\end{tabular}


Note: Greece, Portugal, and Spain are included in industrialized countries in Tables $1-5$ but are shown as developing countries in subsequent tables. Warsaw Pact and People's Republic of China (PRC) are included in Other ROW. The data exclude arms exports and imports of the Soviet Union, other Eastern Bloc countries, and the PRC to one another and to all other countries/regions.

*Indicates that evidence of trade is occurring between the country and region was found in at least one source, but that the exact amount of that trade is not known. 
Table 5

Source and Destination of SITC 951 (Military Goods) for the

Major Western Industrialized and Developing Countries, 1980 (Millions of U.S. Dollars)

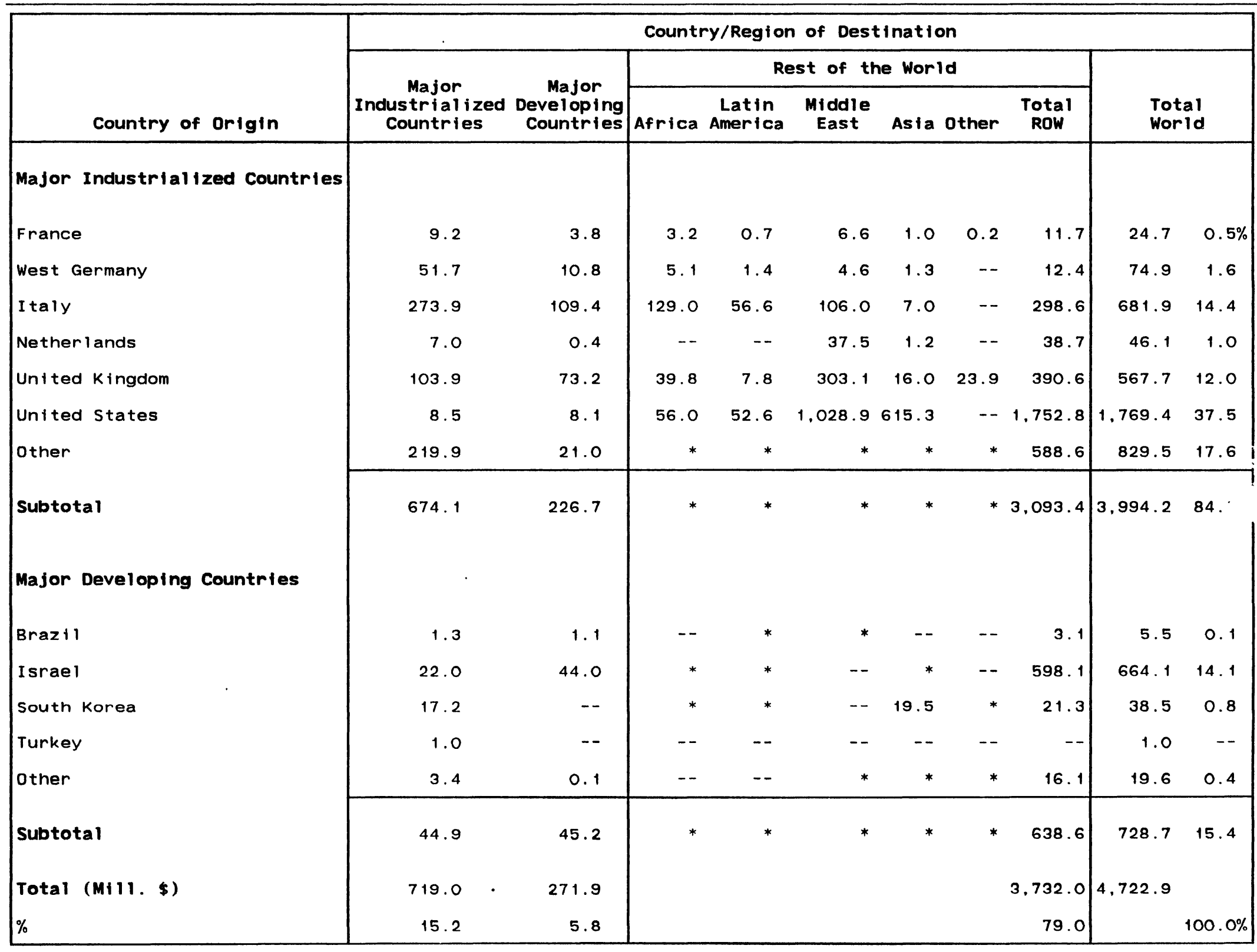


Note: Greece, Portugal, and Spain are included in industrialized countries in Tables 1-5 but are shown as developing countries in subsequent tables. Warsaw Pact and People's Republic of China (PRC) are included in other ROW. The data exclude arms exports and imports of the Soviet Union, other Eastern Bloc countries, and the PRC to one another and to all other countries/regions.

*Indicates that evidence of trade is occurring between the country and region was found in at least one source, but that the exact amount of that trade is not known. 